\title{
Buğdayda Verim Esaslı Azotlu Gübreleme
}

\author{
Bekir ATAR $^{1^{*}}$ \\ ${ }^{1}$ Süleyman Demirel Üniversitesi, Ziraat Fakültesi Eğitim Araştırma ve Uygulama Çiftliği, Isparta \\ [ORCID: http://orcid.org/0000-0002-1446-5699] \\ *Sorumlu yazar: bekiratar@sdu.edu.tr
}

\begin{abstract}
Öz
Buğday üretiminde azot gübrelemesi maliyetli ve zor bir konudur. Uygun azot yönetimi verimi ve kaliteyi arttıırken, fazla azotun çevre üzerinde olumsuz etkisini azaltır. Azotlu gübrelerin ekimle birlikte, kardeşlenme ve mümkünse çiçeklenme döneminde olmak üzere 3'e bölünerek uygulanması azot alım etkinliğini arttırmaktadır. Gelişme döneminde verilen azot tane verimi, son dönemde verilen ise protein oranı üzerinde etkili olmaktadır. Uygulanacak azot miktarıı belirlerken esas olarak topraktaki mevcut azot miktarı ile o tarladan elde edilen ve beklenen tane veriminin bilinmesi gerekir. Beklenen verim; son birkaç yıldaki en düşük ve en yüksek verimler çıkarılarak bulunan ortalama değerin $\% 5$ fazlası olarak kabul edilmektedir. Hasat döneminde verimin ve protein oranının tespit edilerek kaydedilmesi yapılan gübrelemenin doğruluğunu hakkında fikir verecek ve gelecek yıllara referans olacaktır. Protein oranının istenenden yüksek olması fazla gübreleme, düşük olması ise eksik gübreleme yapıldığı anlamına gelecektir.
\end{abstract}

Anahtar Kelimeler: Buğday, Azot, Verim, Protein

\section{Yield-Based Nitrogen Fertilization in Wheat}

\begin{abstract}
Nitrogen fertilization is a costly and difficult issue in wheat production. While optimizing nitrogen management increases yield and quality, it reduces the negative effect of excess nitrogen on the environment. The application of nitrogen fertilizers in three periods, with sowing, in tillering and possibly in flowering, increases the nitrogen uptake efficiency. The nitrogen fertilizer in development period increases the grain yield, while fertilizer in last period increases the protein ratio. When determining the amount of nitrogen to be applied, it is essential to know the amount of nitrogen in the soil, the yield, the expected yield. Expected yield; it is accepted as $5 \%$ more than the average value obtained by subtracting the lowest and highest yields in the last few years. If the yield and protein ratio determine in the harvesting period, the results will provide insight into the correctness of the fertilization and will refer to next years. If the protein is high, it is mean that over fertilized, while if it is low, it is mean that insufficient fertilized.
\end{abstract}

Key Words: Wheat, Nitrogen, Yield, Protein

\section{Giriş}

Ülkemizde yaklaşık 7.7 milyon hektar (245 kg da ${ }^{-1}$ ) daha da düşüktür (TÜiK, alana buğday ekilmekte ve 21.6 milyon ton civarında ürün alınmaktadır. Dekardan alınan ortalama verim oldukça düşük (300 kg da ${ }^{-1}$ ) olup, kuru alanlarda 2015). Bu değer Avrupa ülkelerinin oldukça altında olup, bazılarının (Belçika, Ingiltere, Fransa vb.) yarısından daha azdır (FAO, 2015). Verim değerleri birçok 
faktörün etkisi altında olup, bunlar arasında iklim faktörleri hariç en önemlilerden birisi, belki de en önemlisi, yeterli ve uygun azotlu gübrelemedir. Azot $(\mathrm{N})$, bitkilerin ve hayvanların büyüme ve gelişmesi için gerekli, önemli, makro besin elementlerinden biridir. Eksikliğinde üretimde bir düşüş görüleceği gibi, fazlalığıda, çevreye ciddi zararlar vermektedir. Dünyada yıllık $\mathrm{N}$ tüketimi her yıl \%2.2 civarında artmaktadır ve 2020 yılında 115 milyon tonu geçmesi beklenmektedir (Byrnes ve Bumb, 1998). Türkiye gübre kullanımı (85 $\mathrm{kg} \mathrm{ha}^{-1}$ ) gelişmiş ülkelerin (200 $\mathrm{kg} \mathrm{ha}^{-1}$ ) oldukça gerisindedir. Gübre fiyatları, yıldan yıla istikrarlı bir şekilde artmaktadır (Balta, 2011). Türkiye gübre hammaddesinde büyük oranda dışa bağımlıdır ve yıllık gübre ithalatı 1.5 milyar dolar (2014 yılı) civarındadır (TÜIK, 2015).

Buğday tane verimi kullanılabilir azot varlığı ile doğrudan ilgilidir (Bruckner ve Morey, 1988; Fiez ve ark., 1994) ve buğday üretiminde kârlılık ve satış, azot yönetimine bağlıdır (Sylvester-Bradley, 2009). Bitkinin azot ihtiyacının tam karşılanmaması nedeniyle, düşük verim alınmakta, fazla gübreleme ile ise, çevre kirlenmekte, gübre maliyeti nedeniyle de ekonomik kayıplar olmaktadır. Fransa'da yapılan bir çalışmada azotlu gübre maliyeti, buğday üretiminin \%28'ini oluşturmaktadır (Quievreux, 1997). Bitkiler ihtiyacı olan azotun tamamını gübrelemeden almadığı gibi, uygulanan azotlu gübrenin tamamı da bitkiler tarafından alınmaz. Dolayısı ile azot bütçesini oluşturmak oldukça güçtür.
Doğruya yakın bir gübreleme hesabı yapabilmek için belirleyici faktör hedeflenen verimdir. Hedeflenen ürün geçmişte gerçekleşen verim değerleri ile potansiyel verim arasında yer almalıdır. Geçmişte elde edilen ya da, benzer toprak ve çevre koşullarında elde edilen en yüksek verim, maksimum verim olarak kabul edilebilir ve hedeflenen verimin, ortalama veriminden yüksek, maksimum verimden düşük olması gerekir (Dahnke ve ark., 1988). Girdileri arttırarak verimi de arttırmak mümkündür. Ancak yüksek ve düşük verimde gelir gider arasındaki fark yani, kâr aynı ise, verimi yükseltme çabası çiftçi için bir anlam ifade etmeyecektir.

Son yıllarda, biraz değişim gösterse de, ülkemizde hammaddesi buğday olan ekmeğin tüketimi fazladır ve halkımız günlük enerji ihtiyacının büyük kısmını (Kotancılar ve ark., 1995) ve içeriğinde bulunan thiamin (B1-vitamini), riboflavin (B2-vitamini), pantotenik asit (B3vitamini), nikotonik asit (niasin, pp) ve tokoferol (E-vitamini) gibi insan beslenmesi için gerekli vitaminleri (Hoseney, 1994) buğdaydan yani, ekmekten karşılamaktadır. Son yıllarda, seleksiyon ve melezleme gibi geleneksel metotlarının yanında, biyozenginleştirme (biofortifikasyon) yöntemi gibi, biyoteknolojik yöntemlerle besin içeriği arttırma çalışmaları devam etmektedir. Besin içerikleri açısından en önemli parametrelerden biri buğdayda protein oranıdır. Protein oranı, genetik özellikle belirlenmekle birlikte, azotlu gübre uygulamalarıyla arttırılabilen bir özelliktir. Bu oranın, kışlık kırmızı sert 
buğdaylar için \%11-14 olması istenir (Wysocki ve ark., 2006). Optimum tane verimi için, kritik protein oranı \%11.5 (Goos ve ark., 1982) olarak belirtilmiştir. Ancak, ekmeklik kalitesinin arttırıması için bu oranın \%12.5'den az olmaması istenmektedir. Protein oranını artırmak için maksimum verime ulaşmada, gerekli azot miktarından daha fazla azot uygulamak gerekir. $\mathrm{Bu}$ ise fazladan maliyet gerektirir. Ancak, alıcılar tarafından protein oranı belli bir düzeyde olan (\%12.5) ürünlere, daha fazla fiyat (\%7) uygulanmaktadır (TMO, 2016).

Dünya nüfusunun 2050 yılında 9 milyar olması ve bu artışın daha çok gelişmekte olan ülkelerde (Byrnes ve Bumb, 1998) olması beklenmektedir. Bu durumda, gelişmekte olan ülkeler gıda açısından gelişmiş ülkelere daha çok bağımlı hale gelecektir. Konunun dramatik yönü sadece gıda bakımından değil, gıda üretimi için gerekli gübre hammaddesi bakımından da, dışa bağımlı olmaya devam edecek olmalarıdır. Mevcut arazi ve su varlığının çok fazla arttırılamayacağı düşünülürse, verim artışı ve sürdürülebilir üretimde iyi bir gübreleme programı önem kazanmaktadır. Ülke olarak, hammadde yönünden büyük oranda dışa bağımlı olduğumuz düşünülürse, bitkisel üretimde azot yönetimini iyi anlamamız ve uygulamamı gerekmektedir.

\section{Azot yönetimi}

Buğday azot alımı ve gübre uygulaması

Buğdayın gelişme dönemini azot alım miktarına bağlı olarak, üç döneme ayırmak mümkündür. Birinci dönem, çıkıştan kardeşlenmeye kadar olan süredir ve azot alımı düşüktür (\%5-20). Araştırmalar buğdayın azotu Zadoks' büyüme dönemine (Şekil 2) göre, en yoğun olarak kardeşlenme ve başaklanma (Zadoks' 25-58) periyodunda (Şekil 1) alındığını göstermiştir (Brown ve ark., 2005; Alley ve ark., 2009; Orlof ve ark., 2012). Bu dönemdeki azot, verim üzerine direk etkide bulunan kardeş sayısına ve başaktaki tane sayısına olumlu katkıda bulunmaktadır. Kardeşlenme dönemindeki azot eksikliği verim potansiyeline ulaşmayı engellemektedir (Pumphrey ve Rasmussen, 1982). Şekil 1'de görüldüğü üzere üçüncü dönem, başaklanmadan hasada kadar olan süredir ve bu dönemde azot alımı yavaştır. Ancak bu dönemdeki gübreleme, tane büyüklüğü ve protein oranı üzerinde etkilidir. Buğday bitkisinin büyüme ve gelişme dönemlerinde ihtiyaç duyduğu azotu zamanında toprakta hazır bulundurmak gübrelemenin esas amacıdır. Bu nedenle, gübrelemeyi gelişim dönemlerine göre yapmak, azot kullanım etkinliğini arttırmaktadır.

Önceki üretim döneminden kalan bitki artıklarının mineralizasyonu ve güçlü fide gelişimi için, ilk azotlu gübrenin ekimle birlikte ve tohumla temas etmeden 10 cm derine gömülmesi (Goos, 1983; Campbell ve ark., 1984; Parsons ve Koehler, 1984) önerilmektedir. Bu dönemde uygulanacak $\mathrm{N}$, toplam miktarın \%5-20'lik kısmı (Flowers ve ark., 2007) yada 1.7-2.8 kg da ${ }^{-1,}$ dır (MSU, 2014). Bu dönemdeki verilen azot, verimi 
etkilerken, protein oranı üzerine etkili olmamaktadır. Kış yağışı düşük ve ağır bünyeli toprağa sahip bölgelerde, gerekli gübrenin tamamı bu dönemde verilebilir (Boman ve ark., 1995). Ancak, bölünerek verilmesinin daha faydalı olacağı ve azot kullanım etkinliğini arttıracağı (Sowers ve ark., 1994; Campbell ve ark., 1995; Izaurralde ve ark., 1995; Strong, 1995; Robertson, 1997; Arregui ve Quemada, 2008) yapılan çalışmalarla ortaya konulmuştur.

İkinci gübreleme dönemi

(kardeşlenme ve başaklanma arası) en fazla azotun alındığı ve verim açısından en önemli dönemdir (Pumphrey ve Rasmussen, 1982). Bahar döneminde tek gübreleme yapılacaksa, gübrenin tamamı sapa kalma döneminde (Feekes' 6) yapılmalıdır. Ancak, bu dönemdeki uygulamanın ikiye bölünmesi, olumsuz çevre koşullarında faydalı olabilmektedir. Birinci kısım gübreleme erken ilkbaharda (Feekes' 3-4, Zadoks' 25), ikinci kısım ise geç ilkbaharda (Feekes' 6, Zadoks' 30) yapılmalıdır (MSU, 2014).

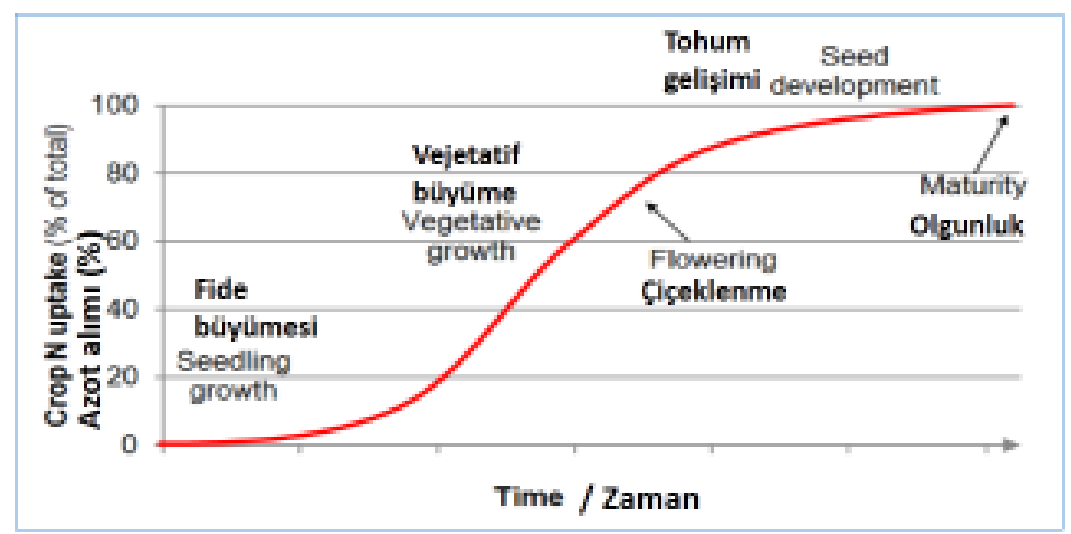

Şekil 1. Buğdayın büyüme periyodunda azot alımı oranları

Figüre 1. Nitrogen uptake of wheat during the growth period

Üçüncü gübreleme dönemi ise çiçeklenme dönemidir. Uygulamalar yapraktan gübreleme şeklinde yapılır. Bu dönemde gübreleme için, özel alet ekipman gerekli olduğundan ve uygulama aşamasında bitkilere zarar verilebildiğinden, çok kullanılmasa da protein oranını attırmada (Orloff ve ark., 2012) ve olası azot eksikliğini telafi etmek için, uygun dönemdir. Başaklanmadan sonra, bitki sap kısmından (Munier ve ark., 2006) ve bayrak yapraktan alınan örneklerde yapılan $\mathrm{N}$ analizleri ile ekstra gübrelemeye gerek olup olmadığı anlaşılabilmektedir. Feekes' büyüme dönemi 10.3 'de, bayrak yaprakların $\mathrm{N}$ içerikleri, protein oranı hakkında fikir vermektedir. İstenen protein oranı düzeyinde değilse (bayrak yaprak N \%4.24.3'den küçükse, Brown ve ark., 2005), bu dönemde gübre ilavesi yapılabilir.

Azotlu gübre çeşitleri ile ilgili yapılan bazı çalışmalarda, sızıntı, yüzey akışı vb. kayıplar olmadığı sürece, verim 
yönünden önemli farklılık olmadığı belirtilmektedir (Pumphrey ve Rasmussen, 1982; Kaiser ve ark., 2013). Yeterli nemin bulunmaması gübrenin etkinliğini sınırlandırabilmektedir (Flowers ve ark., 2007). Toprakta pH 7.3'den büyük, sıcaklık yüksek, toprak yüzeyinde bitki artıkları bulunması gibi problemler, üre ve amonyum nitrat gübrelerinde, kayıpları arttırabilmektedir. Üst gübrenin sabah ya da aksam serinliğinde uygulanması, azotlu gübrenin yapraklara verdiği zararı azaltacaktır. Azotlu gübrenin yüzeyden uygulanması kolaylık ve herbisitlerle beraber uygulanabilme gibi avantajlar sağlasa da, buharlaşma ile azot kaybı olması gibi dezavantajları vardır.

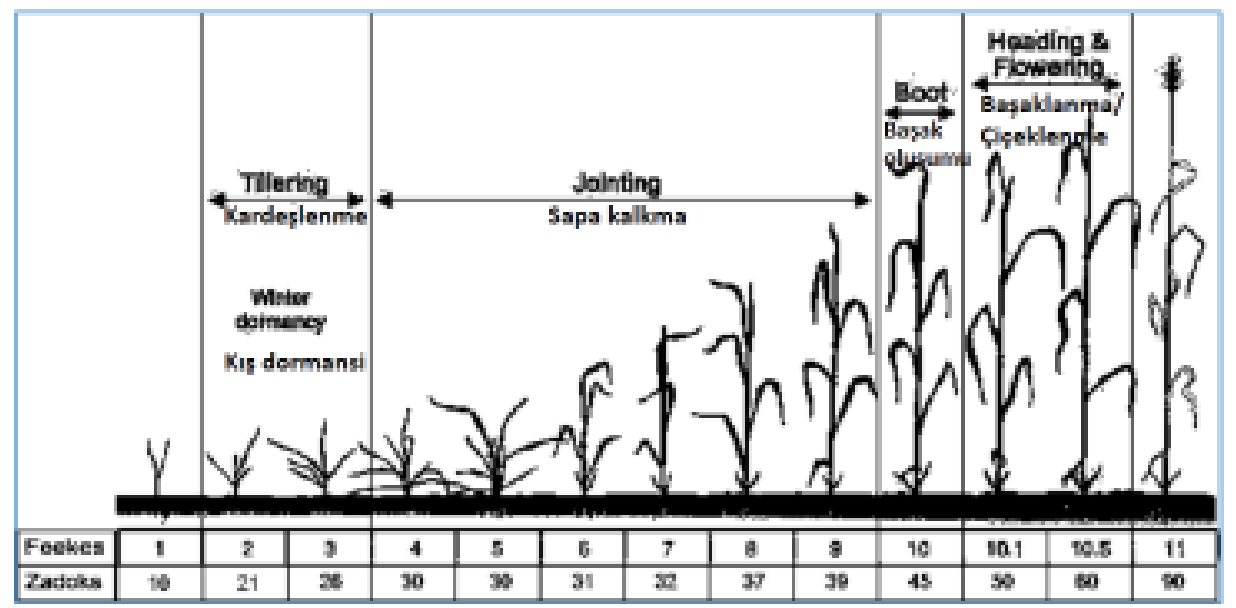

Şekil 2. Buğdayın Zadoks ve Feekes skalasına göre büyüme dönemleri (Large, 1954; Zadoks ve ark., 1974) Figure 2. Wheat growth stages for Zadoks and Feekes scale (Large, 1954; Zadoks ve ark., 1974)

Azot gübrelemesi ve protein oranı ilişkisi

Buğdayda tane verimi ve protein oranı yazlık ve kışlık çeşit (May ve ark., 1991), genetik özellik (Beninati ve Busch, 1992; Le Gouis ve ark., 2000) ile sıcaklık, ekim sıklığı, toprak nemi (Gauer ve ark., 1992; Sajo ve ark., 1992) gibi iklim özelliklerine göre değişsede, en önemli etken toprakta kullanılabilir azot varlığıdır. Verimi etkileyen yetişme koşulları, protein oranı üzerinde de etkilidir (McDermitt ve Loomis, 1981; Brown ve ark., 2005). Yumuşak beyaz buğdayların protein oranı $\% 10$, sert buğdayların \%11-14 olması istenir (Wysocki ve ark., 2006). Kırmızı sert kışlık buğdaylarda protein oranı en az \%12.5, kırmızı sert yazlık buğdaylarda \%14 olması, ekmeklik kalitesi bakımından önemlidir (Flowers ve ark., 2007).

Sert buğdaylarda protein oranını artırmak için, Şekil 3'de görüleceği üzere, maksimum verim için gerekli azot miktarından daha fazla azotlu gübre uygulanması gerekmektedir (Cox ve ark., 1986; Woodard ve Bly, 1998). $100 \mathrm{~kg}$ tane verimi için 2.6 ile $3.3 \mathrm{~kg} \mathrm{da}^{-1} \mathrm{~N}$ uygulandığında maksimum verim alınabilmekte ancak, elde edilen buğdayın protein oranını \%14'e çıkarmak için bu değerin 4.6-5.3 $\mathrm{kg} \mathrm{da}^{-1} \mathrm{~N}$ arasında olması gerektiği belirtilmiştir (Orloff ve ark., 2012). Verimin düşük olduğu, az 
yağış alan yerlerde $(<300 \mathrm{~mm})$ protein oranını \%1 artırmak için $2.5 \mathrm{~kg} \mathrm{da}^{-1} \mathrm{~N}$, verimin yüksek (yağışın yüksek veya sulamanın olduğu alanlar) olduğu yerlerde, yaklaşık $4 \mathrm{~kg} \mathrm{da}^{-1} \mathrm{~N}$ gübrelemesi yapmak gerekir (Pumphrey ve Rasmussen, 1982; Engel ve ark., 2005).

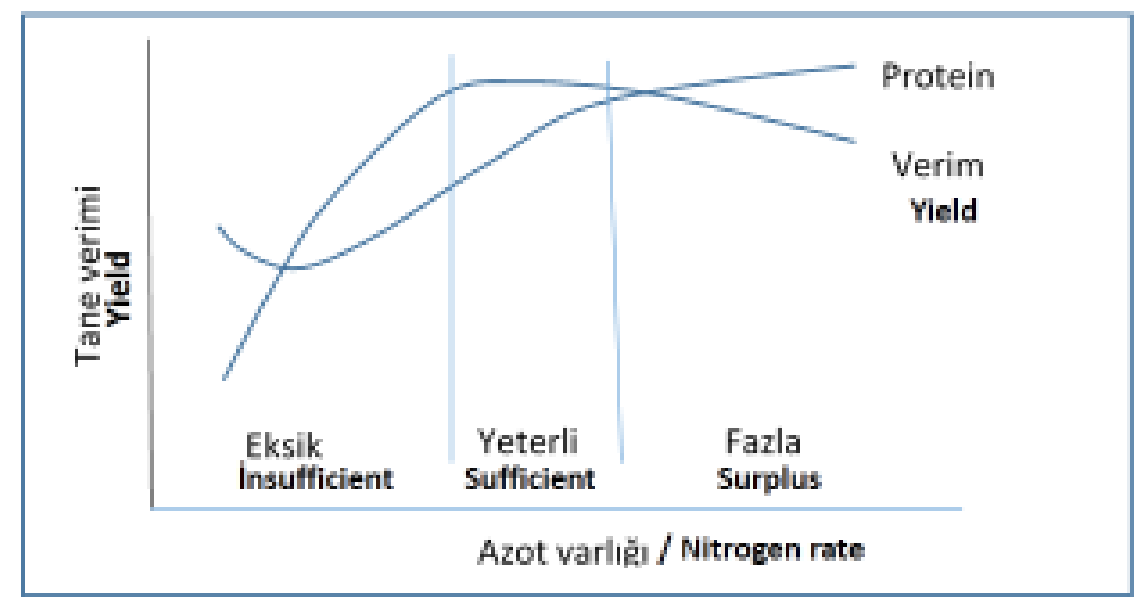

Şekil 3. Kışlık sert buğdaylarda tane verimi ve protein oranı ilişkisi (Terman ve ark., 1969; Campbell ve ark., 1997; Fowler, 2003)

Figure 3. Relationship between grain yield and protein ratio in winter hard wheat (Terman ve ark., 1969; Campbell ve ark., 1997; Fowler, 2003)

Olgunlaşma döneminde (çiçeklenme sonrası), topraktaki mevcut azot varlığı, yani azot gübrelemesi, ile protein oranı arasında doğrudan ilişki bulunmaktadır (Brown ve ark., 2005; Kara, 2010). Mayıs sonunda uygulanacak fazladan $4 \mathrm{~kg} \mathrm{da}^{-1}$ $\mathrm{N}$ gübrelemesi, protein oranını \%0.5-0.7, tane dolum döneminde aynı miktar yaprak gübrelemesi \% 0.75-1 oranında arttırmıştır (Sylvester-Bradley, 2009). Çiçeklenmeden sonra uygulanan (3-6 kg $\mathrm{da}^{-1}$ ) $\mathrm{N}$ gübrelemesi protein oranını arttırmada etkili olmuştur (Wuest ve Cassman, 1992; Bly ve Woodard, 2003; Kaiser ve ark., 2013). Alley ve ark., (2009) yaptıkları çalışmada, tane dolum döneminde 90-140 litre suya 1.1-2.2 kg $\mathrm{da}^{-1}$ üre gübresinin karıştırılarak yaprak- tan uygulanmasının, protein oranını arttırmada etkili olduğunu bildirmiştir.

Gelişme döneminde görülecek yeterli yağışlar, vejetatif aksamın fazlaca gelişmesine neden olacağından, protein oranı düşer, yetersiz yağış nedeniyle düşük vejetatif gelişme, protein oranının artmasına neden olur (Flowersve ark., 2007). Bununla birlikte, ekim döneminde topraktaki nitrat seviyesi ile protein oranı arasında güçlü bir ilişki bulunmuştur (Gerwing ve Gelderman, 1994; Karamanos, 1995). Kükürt eksikliği de, tane protein oranını sınırlandırabilmektedir. İstenen protein oranına ulaşmak için, azot miktarının onda biri kadar yada $3 \mathrm{~kg} \mathrm{da}{ }^{-1}$ kükürt uygulamak gerektiği belirtilmiştir (Flowers ve ark., 2007). Killi topraklarda, istenen protein 
oranını yakalama başarısı kumlu topraklara nazaran, daha yüksektir (Anderson ve Impiglia, 2002). Hayvan gübresi uygulanmış tarlalarda, ortamda mineralizasyon ile devamlı azot bulunması da, protein oranını arttırmada etkili olmaktadır (Brown ve ark., 2005).

\section{Uygulanacak gübre miktarının hesaplanması}

Yapılan çalışmalar açıkça göstermiştir ki, uygulanacak azot miktarını net olarak belirlemek mümkün olamamaktadır. Çünkü, azotun kaynağı (fiksasyon, yağışlar, denitrifikasyon vb.) ve kayıpları (bitki tüketimi, yıkanma, buharlaşma vb.) farklı yollarla olmaktadır. Yapılan çalışmaların amacı, optimum üretim için gerekli miktarı belirlemektir. Yapılan ekonomik analizlerde $700-800 \mathrm{~kg} \mathrm{da}^{-1}$ tane verimi alınan üretimlerde, hesaplanan $\mathrm{N}$ miktarının, $5 \mathrm{~kg} \mathrm{da}^{-1} \mathrm{~N}$ fazla, yada az olması ekonomik kayıplara neden olmamaktadır. Yani, istenen hedefe ulaşılmış kabul edilmektedir (Sylvester-Bradley, 2009). Uygun azot dozundan daha fazla azot kullanımı, vejetatif gelişmeyi teşvik ederek (Schleuber ve Tucker, 1967) verimde düşmelere (McDonald, 1992; Çokkızgın ve Çölkesen, 2006) ve ekonomik kayıplara neden olabilmektedir. Gübre miktarı belirlenirken, toprak özelliklerinin, topraktaki azot miktarının, verim potansiyelinin ve bitkinin büyümesi ile azot alım dinamiklerinin bilinmesi gerekmektedir. Protein oranı dikkate alınmadan, maksimum tane verimi için, olgun tüm buğday bitkisinin, azot oranı \%1.4 (Stanford ve Hunter, 1973) olması gerektiği belirtilmiştir. Gerekli azot miktarı, kaldırılan biyokütle ağırlığının azot oranıyla çarpılmasıyla da belirlenebilmektedir. Yine yapılan çalışmalarda, 1 ton kışlık sert buğday üretimi için, 38-43 kg azot ihtiyacı olduğu belirtilmiştir (Gardner ve ark., 1980). Belirtilen miktarlar, tüm azot kaynaklarından kazanımları içermektedir. Gübreleme ile verilecek azot miktarını belirlemede esas, hedeflenen verim ve protein oranı olmalıdır. Gübre ihtiyacını belirlemede Eşitlik 1 (Sylvester-Bradley, 2009) ve Eşitlik 2 (Halvorson ve ark., 1987; Wysocki ve ark., 2006; Kaiser ve ark., 2013'dan uyarlanmıştır) kullanılabilir. Her iki eşitlikte benzer veriler kullanılmaktadır. Ahır gübresi, rotasyon, aşırı yağış gibi, topraktaki azot miktarını olumlu ve olumsuz yönde etkileyen etmenler olmadığı durumlarda, Eşitlik 1'in kullanımı daha basittir. Eşitlik 2'de ise, azot faktörleri daha ayrıntılı olarak değerlendirilmektedir.

$$
\begin{aligned}
\text { Nnwf }= & \left(G f^{*} \mathrm{Nc}\right)-\mathrm{Ns}-\mathrm{Pe} / \mathrm{Nfr}
\end{aligned} \begin{aligned}
&(\mathbf{1}) \\
& \text { Nnwf }= \mathrm{Gf*Nc}+(\mathrm{Ngy})+\mathrm{Ng}-\mathrm{Ns}-(\mathrm{Npc})- \\
&(\mathrm{Noml})-(\mathrm{Nm})-(\mathrm{Nr})
\end{aligned}
$$

Nnwf; Gübreleme ile uygulanacak saf azot miktarı (kg da $\left.{ }^{-1}\right)$

Gf; Tahmini Verim (kg da ${ }^{-1}$ ); Gübreleme ile uygulanacak azot miktarını doğru şekilde belirlemede esas faktördür. Tahmini verimi etkileyen birçok faktör vardır. Bunlar arasında toprak yapısı, etkili kök derinliği, iklim, toprak işleme sistemi, vb. sayılabilir. Ancak, kuru tarımda yıllık yağış miktarı ve dağılımı verimi etkileyen en önemli faktördür (Halvorson ve ark., 1987). Yıllık yağış 
miktarı $300 \mathrm{~mm}$ 'nin ve organik madde oranı \%1-2 olan alanlarda 250 ile $450 \mathrm{~kg}$ $\mathrm{da}^{-1}$ arasında (Lutcher ve ark., 2007), 300$500 \mathrm{~mm}$ yılık yağış ortalamasında, \%1-3 organik madde içeren, siltli toprakta 350$700 \mathrm{~kg} \mathrm{da}^{-1}$ buğday tane verimi alınabilmektedir (Wysocki ve ark., 2006). Üreticilerin, bulundukları bölgenin verim değerlerini kayıt altına almaları önemlidir. Tahmini verimin, son beş ve üzeri yılların en yüksek ve en düşük değerlerinin çıkarılarak, bulunan ortalamanın, \%5 üstünde olması gerektiği belirtilmiştir (Dinkins ve Jones, 2007).

Nc; Azot ihtiyacı katsayısı; Eşitlik 1'de bu değer, 0.023 olarak belirlenmiştir. Eşitlik 2'de ise, yapılan çalışmalarla çeşit, verim ve iklime bağlı olarak $1 \mathrm{~kg}$ tane verimi için, 0.03 ile 0.05 arasında bir değer olarak belirlenmiştir. Wysocki ve ark. (2006) ve Flowers ve ark. (2007) bu değerin \%11 protein oranı için 0.033, $\% 12$ protein oranı için $0.037, \% 13$ protein oranı için $0.041, \% 14$ protein oranı için 0.043 olması gerektiğini belirtmiştir. Türkiye iç ve geçit bölgelerine, iklim özellikleri ve verim bakımından benzerlik gösteren çalışmada, bu değer 0.037 olarak bulunmuştur (Wysocki ve ark., 2006; Flowers ve ark., 2007).

Ngy; Önceki yıl fazla verim düzeltmesi $\left(\mathrm{kg} \mathrm{da}^{-1}\right)$; bir önceki yıl ortalamadan daha fazla verim alınmış ise, fazladan $\mathrm{N}$ gübrelemesi yapmak gerekir. Örneğin, ortalamalara göre $90 \mathrm{~kg} \mathrm{da}^{-1}$ daha fazla tane verimi alınmış ise, $1.8 \mathrm{~kg} \mathrm{~N} /$ da ilave gübreleme gerekir (Wysocki ve ark., 2006; Flowers ve ark., 2007).

Ns; Toprakta mevcut $\mathrm{N}$ miktarı (kg $\left.\mathrm{da}^{-1}\right)$; Toprak analizi ile etkili kök

derinliğindeki $\mathrm{N}$ miktarının belirlenmesi gerekmektedir. Analizler genellikle sonbahar yada kışın yapılmaktadır ancak, Nisan ayında yapılan analizlerin sezon içi düzeltmelerde dikkate alınması daha doğru olacaktır (Dinkins ve Jones, 2007). Genellikle, $60-120 \mathrm{~cm}$ arası toprak profilinin amonyum ve nitrat azot içeriği belirlenir. İlk $60 \mathrm{~cm}$ 'lik katmanın yeterli olduğunu belirten araştırıcıların (Gerwing ve Gelderman, 1997; Wysocki ve ark., 2006; Kaiser ve ark., 2013) yanında bu derinliğin $90 \mathrm{~cm}$ olması gerektiğini savunan araştırıcılarda vardır (SylvesterBradley, 2009). Bazı çalışmalarda sadece nitrat azotunun miktarı dikkate alınırken, amonyum azotunun da analize dahil edilmesi daha doğru sonuç verecektir. Nitrat ve amonyum dışında, farklı formlarda bulunan azotlar \%5-40 arasında katkı sağlamaktadır (Anderson ve ark., 2010). Ancak, organik maddece zayıf topraklarda bu değer ihmal edilebilir düzeydedir.

Toprak analizi yapılmadığı takdirde, toprak ve iklim yapısı dikkate alınarak, belli bir miktar azot varlığı kabul edilebilir. Ancak, bu değer $3.9 \mathrm{~kg} \mathrm{da}^{-1} \mathrm{~N}$ (Wysocki ve ark., 2006) $5.6 \mathrm{~kg} \mathrm{da}^{-1} \mathrm{~N}$ (Flowers ve ark., 2007) ve $4.5 \mathrm{~kg} \mathrm{da}^{-1} \mathrm{~N}$ (Dinkins ve Jones, 2007) gibi, 3-11 kg da ${ }^{-1}$ $\mathrm{N}$ arasında, geniş bir yelpazede değiştiği belirtilmektedir. Kurak geçen yılın ardından daha yüksek bir azot içeriği, yağışlı bir yılın ardından ise, düşük toprak $\mathrm{N}$ içerikleri gözlenmiştir (Gerwing ve Gelderman, 1997). Yine Çukurova yöresi buğday tarlalarında yapılan çalışmada, 0$60 \mathrm{~cm}$ toprak derinliğinde, $4.8-20.4 \mathrm{~kg}$ 
$\mathrm{da}^{-1} \mathrm{~N}$ tespit edilmiştir (ibrikçi ve ark., 2001).

Npc; Önceki ürün azot katkısı yada, ön bitki kredisi (kg da ${ }^{-1}$ ); Önceki ürün baklagil ise, ekiminden sonra 1 . ve 2 . yıl dikkate alınmalı, sonraki yıllardaki azot katkısı ihmal edilmelidir. Bir önceki ürün azot katkısı, soya fasulyesinde $2.2 \mathrm{~kg} \mathrm{da}^{-1}$, fasülye veya bezelyede $1.1 \mathrm{~kg} \mathrm{da}^{-1}$, yoncada yoğunluğuna bağlı olarak 2.5 ile $7.5 \mathrm{~kg} \mathrm{da}{ }^{-1}$, baklagil bitkisi yeşil gübre olarak $4.5 \mathrm{~kg} \mathrm{da}^{-1}$, iki önceki ürün yoncada ise 2.5 ile $4 \mathrm{~kg} \mathrm{da}^{-1} \mathrm{~N}$ olarak belirlenmiştir (Dinkins ve Jones, 2007; Kaiser ve ark., 2013).

Nolm; Organik madde azot katkısı (kg $\mathrm{da}^{-1}$ ); organik madde $\% 3$ den büyük ise, uygulanacak azot miktarından, yaklaşık 1.7-2.2 $\mathrm{kg} \mathrm{da}^{-1} \mathrm{~N}$ düşülür (Jones ve Kurnick, 2016). Organik madde miktarı $\% 1$ ve daha az ise $1.7-2.2 \mathrm{~kg} \mathrm{da}^{-1} \mathrm{~N}$ ilave edilir (Dinkins ve Jones, 2007). Ülgen ve Yurtseven (1988) ise organik madde miktarının her \%1'lik kısmı için $1 \mathrm{~kg} \mathrm{da}^{-1} \mathrm{~N}$ düşülmesi gerektiğini bildirmişlerdir.

$\mathrm{Nm}$; Çiftlik gübresi azot katkısı (kg da$\left.{ }^{1}\right)$; Çiftlik gübresinde azot organik ve inorganik formlarda bulunmaktadır. Inorganik $\mathrm{N}$ doğrudan bitkiler tarafında alınırken, organik N'in yıllık \%30-50'lik kısmı mikrobiyal aktivite ile bitkinin alabileceği forma dönüşür. Bu süreç, materyalin cinsi, toprak nemi ve sıcaklığına bağlı olarak, 3-4 yıla kadar sürer. Uygulanan çiftlik gübresindeki organik ve inorganik azot içeriği analizlerle belirlenmesi gerekir. Ortalama olarak, kuru sığır gübresinde $\% 2$, at gübresinde $\% 1.7$, koyun gübresinde $\% 4$, tavuk gübresinde \%3.9 N (Follett ve ark.,
1981; Kovancı ve ark., 1989) bulunmakla birlikte, bu değerler hayvanın yaşı, yedirilen yemler, kullanılan yataklığın cinsi, gübrenin saklanma tekniği ve süresi vb. faktörlere bağlı olarak değişiklik göstermektedir (Powers ve ark., 1975; Kaçar ve Katkat, 2009).

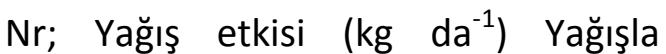
toprağa ilave edilen azot miktarı (2-3 kg $\mathrm{da}^{-1} \mathrm{~N}$ (Sylvester-Bradley, 2009)), ile topraktaki organik maddelerin parçalanması için gerekli azot miktarının (2 $\mathrm{kg} \mathrm{da}^{-1} \mathrm{~N}$ (Halvorson ve ark., 1987)) birbirini karşıladığı kabul edilerek, dikkate alınmayabilir. Toprağın altına sızıntı ile kaybolan $\mathrm{N}$ miktarını dikkate almak için, yıllık yağış ve buharlaşma farklarına bakılır. Fark 200 mm'den fazla ise, ilave azot uygulaması yapılması gerekmektedir.

Nfr; Geri dönüşüm oranı; bir çok toprak tipi için $0.6 \quad(\% 60)$ olarak belirlenmiştir.

Pe: Katsayı ( $\mathrm{kg} \mathrm{da}^{-1}$ ); gübre fiyatı-verim dengesini kurmak için belirlenen katsayıdır ve 1 ( $k$ g $\left.\mathrm{da}^{-1}\right)$ kabul edilmektedir.

Ng; Otlatma katkısı (kg da ${ }^{-1}$ ); Bazı bölgelerde, buğday tarlalarında hayvan beslenmesi amacıyla, sonbahar ve ilkbaharda otlatma yapılmaktadır. Otlatılan her $150 \mathrm{~kg} \mathrm{da}{ }^{-1}$ । Iık kuru otun, 3 kg $\mathrm{N}$ ihtiva ettiği kabul edilmektedir ve bunun telafisi için $4.5 \mathrm{~kg} \mathrm{da}^{-1} \mathrm{~N}$ ilavesi yapılması gerekmektedir.

\section{Uygulanan $N$ dozunun uygunluğunun} değerlendirilmesi

Uygulanan azotun üretime katkısı, azot alım etkinliği, azot kullanım etkinliği, 
agronomik etkinlik, geri dönüşüm etkinliği, fizyolojik etkinlik gibi parametrelerle belirlenmektedir (Moll ve ark., 1982; Dobermann, 2005). Bununla beraber, üretici düzeyinde de değerlendirmeler yapmak gerekir. Uygulanan $\mathrm{N}$ dozunun doğruluğunu gösteren önemli parametrelerden biri elde edilen verimdir. Belirlenen verimde kritik protein oranı kışlık sert buğdaylarda \%11.5 (Goos ve ark., 1982), yazlık buğdaylarda ise \% 14 tür (Goos, 1984). Tahmin edilen verime ve kritik protein oranına yakın değerlerin elde edilmesi, hedeflenen verim açısından uygulanan dozun doğruluğunu gösterecektir. Aksi durumda, gübre miktarının hesaplanmasında yada hedeflenen verimin belirlenmesinde bir hata yapılmış demektir. Uygulanan dozun uygunluğu hakkında diğer bir gösterge ise, tane protein oranıdır. Buğdayın ticari değerini arttırmak için, protein oranının arttırılması gerekmektedir. Bu değer ekmeklik buğdaylarda \%12.5-13'dür. Hasat sonunda, protein oranı hedeflenenden yüksek, yetişme koşulları normal ve tane verimi istenen düzeyde ise; fazla gübreleme yapılmış demektir. Kurak bir yıl geçmesi nedeniyle, verimin düşmesi de protein oranının hedeflenenden yüksek çıkmasına neden olmaktadır. Protein oranı beklenenden düşük (< \%9) ise; gübreleme optimum verim için yetersiz, verim beklenenden yüksek yada, uygulanan azot topraktan buharlaşma yada, derine sızma ile kaybolmuş demektir. Bununla beraber topraktaki $P$ ve $K$ oranlarının düşüklüğü, yabancı ot yoğunluğunun fazlalığı, belirlenen hedeflere ulaşmayı engellemektedir. $\mathrm{Bu}$ kriterler dikkate alınarak değerlendirmeler yapılmalıdır (Pumphrey ve Rasmussen, 1982; Wysocki ve ark., 2006; Sylvester-Bradley, 2009).

\section{Sonuç}

Ülkemiz buğday verim ortalamasının oldukça düşük ve üretim maliyetlerinin yüksek olmasının temel nedenlerinden birisi, azotlu gübre uygulamalarında yapılan hatalardır. Eksik gübreleme düşük verime, fazla gübreleme ise maliyet artışına neden olduğundan, uygulanan gübrenin etkinliği, birim alandan elde edilen geliri optimize etmede, kilit rol oynamaktadır. Üreticilerin kullanabileceği düzeyde, basit ve kolay gübreleme hesabı ve uygulama zamanı bilgileri, azot etkinliğini ve geliri artırmada yararlı olacaktır. Bu bağlamda, yapılan çalışmalar; buğday yetiştiriciliğinde toprakta mevcut $\mathrm{N}$ miktarı, ön bitki etkisi, ön bitki artıkları, toprak organik maddesi, yağış, otlatma gibi, faktörler dikkate alınarak belirlenecek, en uygun $\mathrm{N}$ dozu ve uygulaması sayesinde, hedeflenen verime ulaşılabileceğini göstermektedir.

\section{Kaynaklar}

Alley, M.M., Scharf, P., Brann, D.E., Baethgen, W.E., Hammons, J.L., 2009. Nitrogen Management for Winter Wheat: Principles ve Recommendations. Virginia Cooperative Extension, Publication 424026.

Anderson, W.K., Impiglia, A., 2002. Management of Dryland Wheat. Bread wheat improvement and production. FAO, Rome, 407-432. 
Anderson, N., Hart, J., Christensen, N., Mellbye, M., Flowers, M., 2010. Using the Nitrogen Mineralization Soil Test to Predict Spring Fertilizer N Rate for Soft White Winter Wheat Grown in Western Oregon. Oregon State University Extension Service, EM 9020.

Arregui, L.M., Quemada, M., 2008. Strategies to Improve Nitrogen Use Efficiency in Winter Cereal Crops Under Rainfed Conditions. Agronomy Journal, 100 (2): 277-284.

Balta, O., 2011. Dünyada ve Türkiye'de Gübre Tüketimi. 2. Ulusal Toprak ve Su Kaynakları Kongresi. 22-25 Kasım 2011, Ankara

Beninati, N.F., Busch, R.H., 1992. Grain Protein Inheritance and Nitrogen Uptake and Redistribution in a Spring Wheat Cross. Crop Sci., 32: 1471-1475.

Bly, A.G., Woodard, H.J., 2003. Foliar Nitrogen Application Timing Influence on Grain Yield and Protein Concentration of Hard Red Winter and Spring Wheat. Agron. J., 95: 335-338.

Boman, R.K., Westerman, R.L., Raun, W.R., Jojola, M.E., 1995. Time of Nitrogen Application: Effects on Winter Wheat and Residual Soil Nitrate. Soil Sci. Soc. Am. J., 59: 13641369.

Brown, B., Westcott, M., Christensen, N., Pan, B.,Stark, J., 2005. Nitrogen Management for Hard Wheat Protein Enhancement. University of Idaho Extension, PNW 578.

Bruckner, P.L. Morey, D.D., 1988. Nitrogen Effects on Soft Red Winter Wheat Yield, Agronomic Characteristics, and Quality. Crop Sci., 28: 152-157.

Byrnes, B.H., Bumb, B.L., 1998. Population Growth, Food Production and Nutrient Requirements. Journal of Crop Production, 1 (2): 1-27.

Campbell, C.A., Jame, Y.W., Winkleman, G.E., 1984. Mineralization Rate Constants and Their Use for Estimating Nitrogen Mineralization in Some Canadian Prairie Soils. Canadian Journal of Soil Science, 64 (3): 333-343.

Campbell, C.A., Myers, R.J.K., Curtin, D., 1995. Managing Nitrogen for Sustainable Crop Production. Fertilizer Res., 42: 277-296.

Campbell, C.A., Selles, F., Zentner, R.P., McConkey, B.G., McKenzie, R.C., Brandt, S.A., 1997. Factors İnfluencing Grain N Concentration of Hard Red Spring Wheat in the Semiarid Prairie. Can. J. Plant Sci., 77: 53-62.

Cox, M.C., Qualset, C.O., Rains, D.W., 1986. Genetic Variation for Nitrogen Assimilation and Translocation in Wheat. III. Nitrogen Translocation İn Relation To Grain Yield And Protein. Crop Sci., 26: 737740.

Çokkızgın, A., Çölkesen, M., 2006. Kahramanmaraş Koşullarında Azotlu Gübrenin Makarnalık Buğdayda Verim ve Verim Unsurlarına Etkisi. KSÜ, Fen ve Mühendislik Dergisi, 9 (1): 92-103.

Dahnke, W.C., Swenson, L.J., Goos, R.J., Leholm, A.G., 1988. Chosing a Crop Yield Goal. North Dakota State University Extension, SF-822, USA.

Dinkins, C.P., Jones, C., 2007. Interpretation of Soil Test Reports for Agriculture. Montana State University Extension, MT200702AG, USA.

Dobermann, A.R., 2005. Nitrogen Use EfficiencyState of the Art. University of Nebraska, Agronomy \& Horticulture-Faculty publications, P-316.

Engel, R., Carlson, G., Long, D., 2005. PostHarvest Evaluation of $\mathrm{N}$ Management for Winter Wheat Using Grain Protein. MSU Extension Service, Fertilizer Facts No:34, USA.

FAO, 2015. Food and Agriculture Organization of the United Nations. http://www.fao.org/. Erişim tarihi: 21.11.2016.

Fiez, T.E., Miller, B.C.,Pan, W.L., 1994. Assessment Of Spatially Variable Nitrogen Fertilizer Management in Winter Wheat. J. Prod. Agric., 7: 86-93.

Flowers, M.D., Luthher, L.K., Corp, M.K., Brown, B., 2007. Managing Nitrogen for Yield and Protein in Hard Wheat. Oregon State Universty Extension, FS 335, USA.

Follett, R.H., Murphy, L.S., Donahue, R.L., 1981. Fertilizers and Soil Amendments. Prentice-Hall, Inc., New Jersey, USA.

Fowler, D.B., 2003. Crop Nitrogen Demand and Grain Protein Concentration of Spring And Winter Wheat. Agron. J., 95: 260-265.

Gardner, E.H., Goetze, N.R.,Rasmussen, P.E., 1980. Fertilizer Guide for Winter Wheat. Oregon State University Extension Service

Gauer, L.E., Grant, C.A., Gehl, D.T., Bailey, L.D., 1992. Effects of Nitrogen Fertilization on Grain Protein Content, Nitrogen Uptake, and Nitrogen Use Efficiency of Six Spring Wheat (Triticum Aestivum L.) Cultivars, in 
Relation to Estimated Moisture Supply. Can. J. Plant Sci., 72: 235-241.

Gerwing, J., Gelderman, R., 1994. Nitrogen Management Effects on Wheat Grain Protein. In: Proceedings of the Fifth Great Plains Soil Fertility Conference, pp. 131139, Denver CO.

Gerwing, J., Gelderman, R., 1997. Using Manure as a Nitrogen Fertilizer. South Dakota State University Extension, No: 8132, USA.

Goos, R.J., Westfall, D.G., Ludwick, A.E. Goris, J.E.,1982. Grain Protein Content as an Indicator of $\mathrm{N}$ Sufficiency for Winter Wheat. Agronomy Journal, 74: 130-133.

Goos, R.J., 1983. Small Grain Soil Fertility Investigations, 1979-1983. Farm Research, 41 (1): 27-33.

Goos, R.J., 1984. Post-harvest Evaluation of Nitrogen Management-A New Approach to "Selling Soil Testing to Wheat Farmers". J. Agron. Educ., 13: 103-106.

Halvorson, A.D., Alley, M.M., Murphy, L.S., 1987. Nutrient Requirements and Fertilizer Use. Wheat and Wheat İmprovemen. Editör: Heyne, EG. ASA-CSSA-SSSA, Agronomy M. No:13, USA.

Hoseney, R.C., 1994. Principles of Cereal Science and Technology. American Association of Cereal Chemists. Ins. St. Paul, USA.

Izaurralde, R.C., Feng, Y., Robertson, J.A., McGill, W.B., Juma, N.G.,Olson, B.M., 1995. LongTerm Influence of Cropping Systems, Tillage, Tillage Methods, and N Sources on Nitrate Leaching. Can. J. Soil Sci., 75: 497505.

İbrikci, H., Buyuk, G., Yagbasanlar, T., Keklikci, Z., Toklu, F., Guzel, N., Ozkan, H., 2001. Contribution of Soil Mineral Nitrogen in Wheat Production. Journal of Plant Nutrition, 24 (12): 1871-1883.

Jones, C., Kurnick, R., 2016. Fertilizer Rate Calculations. Montana State Uni. Extension, MT 59717.

Kacar, B., Katkat, A.V., 2009. Gübreler ve Gübreleme Tekniği. Nobel Yayın Dağıtım Ltd. Şti. Yayınları, Yayın no:1119, Ankara.

Kaiser, D.E., Lamb, J.A., Sims, A., Wiersma, J., 2013. Nutrient Management (Fertilizing Wheat in Minessota). Universty of Minnesota, AG-Fo-3814-C, USA.

Kara, B., 2010. Influence of Late-Season Nitrogen Application on Grain Yield, Nitrogen Use Efficiency and Protein Content of Wheat Under Isparta Ecological
Conditions. Turkish Journal of Field Crops, 15 (1): 1-6.

Karamanos, R.E., 1995. Recent Trends in Nutrient Levels, Crop Quality and Fertilization, pp. 265-273. In: Proceedings of the Western Canada Agronomy Workshop. Vol. II. Red Deer AB, PPI, Canada.

Kotancılar, G., Çelik, İ., Ertugay, Z., 1995. Ekmeğin Besin Değeri ve Beslenmedeki Önemi. Atatürk Üni. Zir. Fak. Der., 26 (3): 431-441.

Kovancı, İ., Hakererler, H., Oktay M., 1989. Tavuk Gübresi İle Çöp Gübresinin Tarımda Organik Gübre Olarak Kullanılmasına Dair Bir Araştırma. E.Ü. Araştırma fonu, Proje no:113, İzmir.

Large, E.G., 1954. Growth Stages in Cereals: Illustration of the Feeke's scale. PI. Path., 3: 128-129.

Le Gouis, J., Beghin, D., Heumez, E., Pluchard, P., 2000. Genetic Differences for Nitrogen Uptake and Nitrogen Utilisation Efficiencies in Winter Wheat. European Journal of Agronomy, 12 (3): 163-173.

Lutcher, L.K., Horneck, D.A., Wysocki, D.J., Hart, J.M., Petrie, S.E., Christensen, N.W., 2007. Winter Wheat in Summer-Fallow Systems (Low precipitation zone). Oregon State University Extension Service, FG 80, USA.

May, L., Van Sanford, D.A., MacKown, C.T., Cornelius, R.L., 1991. Genetic Variation for Nitrogen Use in Soft Red $X$ Hard Red Winter Wheat Populations. Crop Sci,. 31: 626-630.

McDermitt, D.K., Loomis, R.S., 1981. Elemental Composition of Biomass and its Relation to Energy Content, Growth Efficiency, and Growth Yield. Ann. Bot., 48: 275-290.

McDonald, G.K., 1992. Effects of Nitrogenous Fertilizer on the Growth, Grain Yield and Grain Protein Concentration of Wheat. Australian Journal of Agricultural Research, 43: 949-967.

Moll, R.H., Kamprath, E.J., Jackson, W.A., 1982. Analysis and Interpretation of Factors Which Contribute to Efficiency of Nitrogen Utilization. Agronomy Journal, 74 (3): 562564.

MSU, 2014. Wheat Production in Mississippi. Mississippi State University. http://msucares.com/crops/wheat, Erişim tarihi: 25 Aralık 2014.

Munier, D., Kearney, T., Pettygrove, G., Brittan, K., Mathews, M., Jackson, L., 2006. Fertilization of Small Grains. Small Grain 
Production Manual. University of California Division of Agriculture and Natural Resources Publication 8167.

Protein.California Alfaalfaand Grain Semposium. December 11-12, Sacramento, USA.

Parsons, B.C., Koehler, F.E., 1984. Fertilizer use by spring wheat as affected by placement. In Proceedings, Thirty-Fifth Annual Northwest Fertilizer Conf.

Powers, W.L., Wallingford, G.W., Murphy, L.S., 1975. Research Status on Effects of Land Application of Animal Manure. EPS-660/275-010. US Government Printing Office, Washington, DC 20402.

Pumphrey, F.V., Rasmussen, P.E., 1982. Winter Wheat Fertilization in the Northeast intermountain Region of Oregon. Circular of Information 691. Oregon State University, USA.

Quievreux, D., 1997. Réseau d'observation de parcelles de céréales. Résultats de la Récolte 1997, Chambre d'Agriculture de la Somme, Amiens, France.

Robertson, G.P., 1997. Nitrogen Use Efficiency in Row-Crop Agriculture: Crop Nitrogen Use and Soil Nitrogen Loss. In: Ecology in Agriculture. Jackson, L. (ed.). Academic Press, New York. pp. 347-365.

Sajo, A.A., Scarisbrick, D.H., Clewer, A.G., 1992. Effect of Rates and Timing of Nitrogen Fertilizer on the Grain Protein Content of Wheat (Triticum Aestivum), Grown in Two Contrasting Seasons in South East England. J. Agric. Sci., 118: 265-269.

Schleuber, A.M., Tucker, B.B., 1967. Culture of Wheat. pp. 117-118. In: K.S. Quinsenberry and L.P. Reitz (eds.), Wheat and Wheat Improvement. American Society of Agronomy, Madison, WI.

Sowers, K.E., Miller, B.C., Pan, W.L., 1994. Optimizing Yield and Grain Protein in Soft White Winter Wheat with Split Nitrogen Applications. Agron. J., 86: 1020-1025.

Stanford, G., Hunter, A.S., 1973. Nitrogen Requirements of Winter Wheat (Triticum
Orloff, S., Wright, S., Ottman, M., 2012. Nitrogen Management Impacts on Wheat Yield And

aestivum, L.) Varieties 'Blueboy'and 'Redcoat'. Agronomy Journal, 65 (3): 442447.

Strong, W.M., 1995. Nitrogen Fertilization of Upland Crops. p. 129-169. In P.E. Bacon (ed.) Nitrogen Fertilization in the Environment. Marcel Dekker, New York.

Sylvester-Bradley, R., 2009. Nitrogenfor Winter Wheat-Management Guidelines. HGCA Guide 48 (G48).

Terman, G.L., Ramig, R.E., Dreier, A.F., Olson, R.A., 1969. Yield-Protein Relationships in Wheat Grain, as Affected by Nitrogen and Water. Agron. J., 61: 755-759.

TMO, 2016. Toprak Mahsulleri Ofisi. http://www.tmo.gov.tr/, Erişim tarihi: 22.11.2016.

TÜiK, 2015. Türkiye İstatistik Kurumu. http://www.tuik.gov.tr, Erişim tarihi: 15.11.2016.

Ülgen, N., Yurtsever, N., 1988. Türkiye Gübre ve Gübreleme Rehberi. Toprak ve Gübre Araştırma Enstitüsü Müdürlüğü Yayınları. Genel yayın no:151, Ankara.

Woodard, H.J., Bly, A., 1998. Relationship of Nitrogen Management to Winter Wheat Yield and Grain Protein in South Dakota. Journal of Plant Nutrition, 21 (2): 217-233.

Wuest, S.B., Cassman, K.G., 1992. FertilizerNitrogen Use Efficiency of Irrigated Wheat: II. Partitioning Efficiency of Preplant Versus Late-Season Application. Agron. J., 84: 689-694.

Wysocki, D.J., Horneck, D.A., Lucther, L.K., Hart, J.M., Petrie, S.E., Corp, M.K., 2006. Winter Wheat in Continious Cropping Systems (Intermediate precipitation zone). Oregon State Universty Extension Service, FG 83, USA.

Zadoks, J.C., Chang, T.T., Konzak, C.F., 1974. A Decimal Code For Growth Stage Of Creals. Weed. Res., 14: 415-421. 